\title{
An Analysis of Energy Consumption in the Campus Building's Operation (Case Study: The Building of Faculty of Engineering and Department of Civil and Environmental Engineering, Universitas Gadjah Mada)
}

\author{
Syarifudin \\ Politeknik Negeri Nunukan, Nunukan, INDONESIA \\ syarifudisya@gmail.com \\ Ashar Saputra \\ Department of Civil and Environmental Engineering, Universitas Gadjah Mada, Yogyakarta, INDONESIA \\ saputra@ugm.ac.id \\ Suprapto Siswosukarto \\ Department of Civil and Environmental Engineering, Universitas Gadjah Mada, Yogyakarta, INDONESIA \\ suprapto.siswosukarto@ugm.ac.id
}

\begin{abstract}
Energy Consumption Intensity (IKE) is an indicator that is used to determine the amount of energy used per area by an airconditioned building within a month or a year as a reference to determine how much energy conservation can be done in the building. To determine the energy consumption of buildings and to determine the savings opportunities, there should be an effort to review the energy consumption through energy audits. In this research, energy consumption analysis was conducted at the Main Office building of the Faculty of Engineering (KPFT) and Department of Civil Engineering and Environmental (CEED) of Universitas Gadjah Mada Yogyakarta. The analysis was conducted on the main variables of energy efficiency, namely: measurement of temperature and relative humidity, calculation of Overall Thermal Transfer Value (OTTV) and Roof Thermal Transfer Value (RTTV), calculation of Energy Consumption Intensity (IKE) in air-conditioned and non-airconditioned rooms as well as an analysis of opportunities to increase the efficiency of energy consumption in the buildings. The results showed that the temperature and the relative humidity of the KPFT building $=28.4^{\circ} \mathrm{C}$ and $62 \%$, while $\mathrm{CEED}$ Building $=28.4^{\circ} \mathrm{C}$ dan $65 \%$. Calculation of average OTTV of the KPFT building $=17.61 \mathrm{~W} / \mathrm{m}^{2}$ and CEED building $=43.05$ $\mathrm{W} / \mathrm{m}^{2}$. Average IKE of the KPFT building in 2015 was $3.25 \mathrm{kWh} / \mathrm{m}^{2} / \mathrm{month}$ and in 2016 was $3.45 \mathrm{kWh} / \mathrm{m}^{2} / \mathrm{month}$, while the average IKE of CEED building in 2015 was $1.5 \mathrm{kWh} / \mathrm{m}^{2} / \mathrm{month}$ and in 2016 was $0.79 \mathrm{kWh} / \mathrm{m}^{2} / \mathrm{month}$. Based on the calculation of IKE in both buildings, they are still considered in the category of efficient. However, based on the measurement of temperature and relative humidity, it shows that in both buildings air conditioning is still necessary to achieve the level of thermal comfort, therefore an increase of efficiency in the load is needed to avoid wastage.
\end{abstract}

Keywords: Energy Audit, IKE, Conventional Building, Thermal Comfort.

\section{INTRODUCTION}

Nowadays it cannot be denied that energy has become a basic need that has an important role as a stimulus of almost all economic and social activities in the society. As a means of infrastructure supporting those activities, buildings also have a high level of need for energy for their operational activities.

Energy consumption in buildings should have been planned and agreed upon from the initial planning between planners, owners and contractors/ implementers so that material selection, determination of design as well as electrical equipment used such as lights, air conditioners, and electrical appliances are more energy efficient (Ministry of Energy and Mineral Resources, 2012). For buildings that have been built conventionally, there should be an effort to review energy consumption through energy audits to determine the profile of energy usage and energy savings opportunities so that it can increase the efficiency of energy usage. This paper describes the use of energy consumption as one of the dominant aspects that determines the cost efficiency in building operation.

Universitas Gadjah Mada (UGM) of Yogyakarta as one of the best universities in Indonesia should have applied the savings or efficiency in the use of energy in the operational activities of the buildings. Considering that there has been no calculation analysis of energy consumption in the KPFT, used as administrative building of engineering faculty, and in CEED's building, used as a lecture building, the energy use in both buildings cannot be categorized as 
efficient, yet. Therefore, energy audit activities are necessary to be carried out.

Purposes of the researchs are to figure out the value of energy consumption intensity and the existing energy usage profile in the operational activities of KPFT building and CEED building of UGM Yogyakarta in the last 2 years, 2015 and 2016, to figure out the application of several major variables of energy efficiency namely; temperature setting and relative humidity of air, value of OTTV and RTTV at KPFT building and CEED building of UGM Yogyakarta, and to determine alternative methods of energy conservation to make energy savings as well as cost savings based on real conditions.

\section{LITERATURE REVIEW}

Marzuki and Rusman (2012) conducted a study of Energy Audit on Building Director of PT. Perkebunan Nusantara XIII (Persero). Analysis of energy consumption was carried out through a comprehensive energy audit on a building by calculating the Energy Consumption Intensity (IKE) Gross, as well as Net IKE. The results show that the composition of the use of energy is divided into three groups, namely; lighting expenses $4.54 \%$, air conditioner (AC) $57.36 \%$ and other office equipment $38.10 \%$. The potential savings from the difference energy use of conventional AC replacement with energy-efficient $\mathrm{AC}$ inverters for all office buildings is significant. In addition, Replacement of TL lamps with LED lamps that have a much lower heat can reduce the workload of AC to make it more energy efficient in lighting systems. Yuliatna (2015) conducted a study on the comparison of energy consumption in buildings with the concept of green building and conventional buildings. This research was carried out by calculating the value of OTTV and RTTV and the value of Energy Consumption Intensity (IKE). Result of analysis of several research variables; namely temperature, relative humidity, OTTV, RTTV, (IKE) show that buildings with green building concept have better energy audit results compared to conventional buildings.

\section{RESEARCH METHOD}

Based on Inpres No.13 year 2011 on energy and water conservation, it is necessary to do energy management so that energy usage, especially electric energy becomes more efficient (Syarifudin, 2017). The purpose of the energy audit is to study the profile of energy use and energy saving opportunities so as to improve the efficiency of energy use.
The energy audit is a thorough study of the calculation of Energy Consumption Intensity (IKE), either in the form of IKE Gross, or IKE Netto. Based on the energy conservation standards used by the Ministry of National Education of the Republic of Indonesia and ASEAN - USAID, the intensity of energy consumption (IKE) in buildings is classified into two parts: air-conditioned and non-AC rooms (ASEANUSAID, 1992).

Indonesian National Standard (SNI) 6389-2011 provides guidance on design criteria, energy conservation, and recommendations for the optimal building envelope as well as SNI 6197-2011 (Badan Standarisasi Nasional, 2011) rules procedure of energy audit for building so that energy use can be efficient without compromising comfort and work productivity (Badan Standarisasi Nasional, 2011). In calculating the value of Overall Thermal Transfer Value (OTTV) there are several variables that must be studied, namely; the absorbance value of solar radiation, wall thermal transmittance $\left(\mathrm{W} / \mathrm{m}^{2 \circ} \mathrm{C}\right)$, window to wall ratio or the ratio of the width of the window to the entire outer wall in the specified orientation, the difference in the equivalent temperature between the outer and inner side, solar factor or solar radiation factor in orientation determined $\left(\mathrm{W} / \mathrm{m}^{2}\right)$, and shading coefficient or shade coefficient of the fenestration /aperture system. In addition to OTTV, RTTV (roof thermal transfer value) is also calculated to define the thermal transfer for roof area. RTTV is calculated by considering several factors, as follows; a transparent roofing area $\left(\mathrm{W} / \mathrm{m}^{\circ} \mathrm{C}\right)$, the difference between the outer and inner side $\left({ }^{\circ} \mathrm{C}\right)$, the width of the roof light hole $\left(\mathrm{m}^{2}\right)$, the roof hole transmittance $\left(\mathrm{W} / \mathrm{m}^{\circ} \mathrm{C}\right)$, the temperature difference between the outer and inner planning conditions $\left({ }^{\circ} \mathrm{C}\right)$, and shading coefficient or coefficient of roof hole lightning (Krishan, 2001).

Considering that there has been no audit on energy consumption in Faculty of Engineering (KPFT) building and Civil Engineering and Environment Department (CEED) building of Universitas Gadjah Mada University, the efficiency use of energy consumption in both buildings cannot yet be determined, therefore an energy audit is necessary.

\section{RESULTS AND DISCUSSIONS}

\subsection{Measurements of temperature and relative humidity}

Measurements of temperature and relative humidity were conducted directly at the KPFT building and the CEED building. Measurement of these two variables was performed using a Thermohygrometer by taking 
some of the main rooms on each floor as samples. In each room, the measurement took approximately 5 to 10 minutes while the air was not being conditioned (AC turned was off). Measurements were conducted on holidays (Saturdays and Sundays) 3 times with a three-week rest at each measurement in each of the buildings between November 2016 and January 2017. Measurements were carried out in the morning at 07.00-09.00 am noon at 11.00-13:00 pm and the afternoon at 15.00-17:00 pm.

By the time of the measurement, it was figured out that the sun inclining on the south side of the building, thus affecting the measurement results conducted on the rooms located on the south side of the building. Result recapitulation of temperature and relative humidity measurement in KPFT and CEED buildings is presented in Table 1.

Table 1 shows that the average air temperature of the KPFT building is 28.4 with a relative humidity ( $\mathrm{RH})$ of $62 \%$ and the average temperature of the CEED building is 28.4 with a relative humidity (RH) of $65 \%$. Based on the standard by SNI regarding thermal comfort that the relative humidity is about $60 \%$ and the temperature is between $20.5-22.8$ (comfortably cool), 22.8 - 25.8 (Optimum Comfort), 25.8-27.1 (almost comfortable), it was revealed that air conditioning is still needed in both buildings.

\subsection{OTTV dan RTTV Calculation}

\subsubsection{KPFT building}

OTTV calculations on this building were done directly on the $2^{\text {nd }}$ and $3^{\text {rd }}$ floors. The calculation was not performed on the 1st floor because it is an open space since there is no wall so that calculation was not applicable. In addition to OTTV calculations, roof RTTV calculations were also performed.

The material used in the $2^{\text {nd }}$ floor wall of the north side is normal solid concrete as thick as $152 \mathrm{~mm}\left(\alpha_{\mathrm{w}}=\right.$
0.86 ), brick specific gravity $(\rho)=2,400 \mathrm{~kg} \cdot \mathrm{m}^{3}$, transmittance $(U)=3.58 \mathrm{~W} / \mathrm{m}^{30} \mathrm{C}$, with slightly shiny white color finishing ( $\alpha \rho=0.30)$, window glass is clear glass with shading coefficient $(S C)=0.86$. So, the weight of the wall per $\mathrm{m}^{2}$ is:

$\rho=$ weight $/$ volume

weight $=(\rho)(\mathrm{V})=\left(2,400 \mathrm{~kg} \cdot \mathrm{m}^{3}\right)\left(1 \times 1 \times 0.152 \mathrm{~m}^{3}\right)$ $=354.8 \mathrm{Kg}$

for $354.8>195$, equivalent temperature difference obtained $\left(\Delta \mathrm{T}_{\mathrm{eq}}\right)=10 \mathrm{~K}$.

Wall Absorption is combination between the absorption of wall materials that is normally solid concrete and absorption coat paint (white slightly shiny).

Wall Absorption $(\alpha)=\left(\alpha_{w}+\alpha_{p}\right) / 2=(0.86+0.30) / 2=0.58$

Window Size L2 $(A 1)=\left(1.8 \times 21.4 \mathrm{~m}^{2}\right)+\left(4 \times 4 \mathrm{~m}^{2}\right)=$ $54.52 \mathrm{~m}^{2}$

Wall and window size L2 $(A 2)=\left(5 \times 77.2 \mathrm{~m}^{2}\right)=386 \mathrm{~m}^{2}$

Window to wall ratio $(W W R)=54.52 / 386=0.14$

Solar factor $(S F)$ north side $=130 \mathrm{~W} / \mathrm{m}^{2}$

OTTV $_{\text {North }}=\alpha\left[(U(1-W W R)] \Delta \mathrm{T}_{\mathrm{eq}}+(S C)(W W R)(S F)\right.$

$=0.58\left[(3.58(1-0.14)](10)+(0.86)(0.14)(130)=33.51 \mathrm{~m}^{2}\right.$

Then, with the same calculation method, calculations are performed on all floors for each orientation, with the results as shown in Table 2 below.

Table 2. Recapitulation of OTTV value in KPFT building.

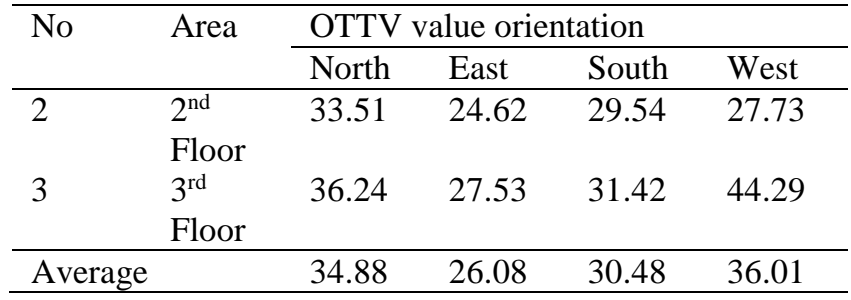

Table 1. Result of temperature and relative humidity measurement in KPFT and CEED building.

\begin{tabular}{|c|c|c|c|c|c|c|c|}
\hline \multirow[t]{2}{*}{ No } & \multirow[t]{2}{*}{ Time } & & & \multicolumn{2}{|c|}{ KPFT } & \multicolumn{2}{|c|}{ CEED } \\
\hline & & & & \multicolumn{2}{|c|}{ Temperature $\left({ }^{\circ} \mathrm{C}\right)$} & \multicolumn{2}{|c|}{$\mathrm{RH}(\%)$} \\
\hline \multirow[t]{3}{*}{1} & Day 1 & Morning & $07: 00$ to $09: 00$ & 27.5 & 63 & 27.4 & 68 \\
\hline & $28 / 11 / 16$ & Noon & $11: 00$ to $13: 00$ & 28.5 & 62 & 29.0 & 65 \\
\hline & & Afternoon & $16: 00$ to $18: 00$ & 29.4 & 62 & 29.5 & 64 \\
\hline \multirow[t]{3}{*}{2} & Day 2 & Morning & 07:00 to $09: 00$ & 27.2 & 66 & 27.5 & 67 \\
\hline & $11 / 28 / 16$ & Noon & $11: 00$ to $13: 00$ & 28.3 & 62 & 28.6 & 65 \\
\hline & & Afternoon & $16: 00$ to $18: 00$ & 29.8 & 60 & 28.7 & 65 \\
\hline \multirow[t]{4}{*}{3} & Day 3 & Morning & $07: 00$ to $09: 00$ & 27.3 & 62 & 27.1 & 67 \\
\hline & $28 / 11 / 16$ & Noon & $11: 00$ to $13: 00$ & 28.3 & 61 & 28.9 & 65 \\
\hline & & Afternoon & $16: 00$ to $18: 00$ & 29.5 & 63 & 29.2 & 63 \\
\hline & Average & & & 28.4 & 62 & 28.4 & 65 \\
\hline
\end{tabular}


Based on the conducted OTTV calculation and on the standard set by SNI with maximum OTTV value of 45 $\mathrm{W} / \mathrm{m}^{2}$, it was revealed that the OTTV value of the whole orientation of the wall of the KPFT building is still below the specified threshold.

Then, RTTV calculation in the KPFT building by using the following method; roof material is clay tile with transmittance value $(U)=1.7 \mathrm{~W} / \mathrm{m}^{2}{ }^{\circ} \mathrm{C}$ and $\alpha=$ 0.8 . Roof area $=1,982.4 \mathrm{~m}^{2}$. Shading coefficient $(S C)$ and solar factor $(S F)$ value are not needed because the roof of the CEED building does not have any skylight. Weight roof per $\mathrm{m}^{2}$ is determined by calculating the total weight of all components per $\mathrm{m}^{2}$. From the calculation result, it is assumed that weight per $\mathrm{m}^{2}=$ $200 \mathrm{~kg}$, so that $\Delta \mathrm{T}_{\mathrm{eq}}=20 \mathrm{~K}$ or ${ }^{\circ} \mathrm{C}$.

$\mathrm{RTTV}=\left[\left(\mathrm{A}_{\mathrm{r}}\right)\left(\mathrm{U}_{\mathrm{r}}\right)\left(\Delta \mathrm{T}_{\mathrm{eq}}\right)+\left(\mathrm{A}_{\mathrm{s}}\right)\left(\mathrm{U}_{\mathrm{s}}\right)(\Delta \mathrm{T})+\left(\mathrm{A}_{\mathrm{s}}\right)\right.$ $(\mathrm{SC})(\mathrm{SF})] /\left(\mathrm{A}_{\mathrm{r}}+\mathrm{A}_{\mathrm{r}}\right)$

$=[(1982.4)(1.7)(20)+(0)+(0)] /(1982.4+0)=34 \mathrm{~W} / \mathrm{m}^{2}$

OTTV $_{\text {total }}=\left[\left(\mathrm{A}_{\text {north }} \mathrm{x}\right.\right.$ OTTV $\left._{\text {north }}\right)+\left(\mathrm{A}_{\text {east }} \mathrm{x} \mathrm{OTTV}_{\text {east }}\right)+$ $\left(\mathrm{A}_{\text {south }} \mathrm{x}\right.$ OTTV $\left.\mathrm{OTouth}\right)+\left(\mathrm{A}_{\text {west }} \mathrm{X} \mathrm{OTTV}_{\text {west }}\right)+\left(\mathrm{A}_{\text {roof }} \mathrm{x}\right.$ $\left.\left.\mathrm{OTTV}_{\text {roof }}\right)\right] /\left(\mathrm{A}_{\text {north }}+\mathrm{A}_{\text {east }}+\mathrm{A}_{\text {south }}+\mathrm{A}_{\text {west }}+\mathrm{A}_{\text {roof }}\right)$

$=[(782 \times 34.88)+(412 \times 26.08)+(782 \times 30.84)$ $+(412 \times 36.01)+(1982.4 \times 34)] /(782+412+782+$ $412+1982.4)=17.61 \mathrm{~W} / \mathrm{m}^{2}$

Based on the conducted calculation, results of OTTV and RTTV calculations on KPFT building on each wall orientation are; the north wall of $34.88 \mathrm{~W} / \mathrm{m}^{2}$, the east wall of $26.08 \mathrm{~W} / \mathrm{m}^{2}$, the south wall of 30.84 $\mathrm{W} / \mathrm{m}^{2}$ and the west wall of $36.01 \mathrm{~W} / \mathrm{m}^{2}$ and RTTV roof at $34 \mathrm{~W} / \mathrm{m}^{2}$.

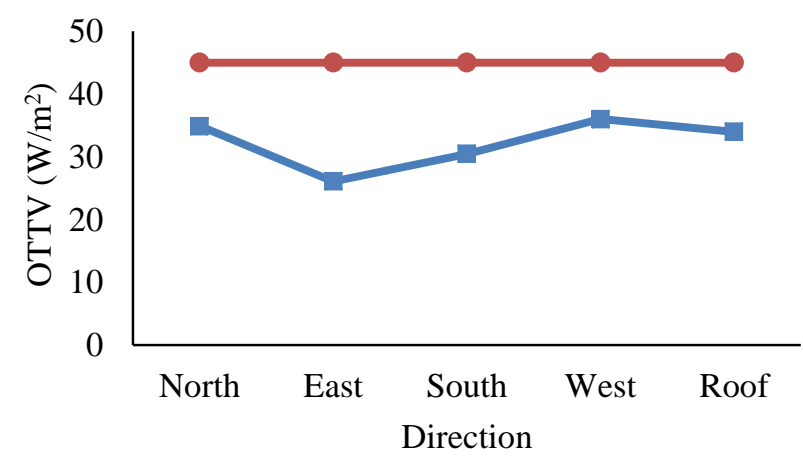

- KPFT's OTTV $\longrightarrow$ OTTV Standard

Figure 1. Comparison OTTV value with SNI on KPFT building.

The comparison on Figure 1 shows that OTTV value of all orientation of the entire wall of KPFT building is still below the threshold of the SNI, which amounted to $45 \mathrm{~W} / \mathrm{m}^{2}$.

\subsubsection{CEED building}

Similar to the calculation method performed on the KPFT building, OTTV calculations on CEED building are performed floor per floor in each direction of wall orientation. Recapitulation of OTTV calculation on 1st - 3rd floor for the four sides of the building wall of CEED building are presented in Table 3 below.

Table 3. Recapitulation of OTTV value in CEED building.

\begin{tabular}{llllll}
\hline \multirow{2}{*}{ No } & Area & \multicolumn{4}{c}{ OTTV value orientation } \\
\cline { 3 - 6 } & & North & East & South & West \\
\hline 1 & $1^{\text {st }}$ Floor & 49.94 & 36.31 & 37.89 & 70.33 \\
2 & $2^{\text {nd }}$ Floor & 52.71 & 37.22 & 37.75 & 95.06 \\
3 & $3^{\text {rd }}$ Floor & 50.68 & 37.39 & 37.85 & 69.86 \\
\hline \multicolumn{2}{l}{ Average } & 51.11 & 36.97 & 37.83 & 78.42 \\
\hline
\end{tabular}

Based on the calculations that have been done, the results of OTTV and RTTV calculations on CEED buildings on each wall orientation are; the north wall $=51.11 \mathrm{~W} / \mathrm{m}^{2}$, the east wall $=36.97 \mathrm{~W} / \mathrm{m}^{2}$, the south wall $=37.83 \mathrm{~W} / \mathrm{m}^{2}$ and the west wall $=78.42 \mathrm{~W} / \mathrm{m}^{2}$.

Based on Figure 2, OTTV values of east and south walls remain below the threshold while for the north and west walls' OTTV value are above the standard threshold SNI, which amounted to $45 \mathrm{~W} / \mathrm{m}^{2}$.

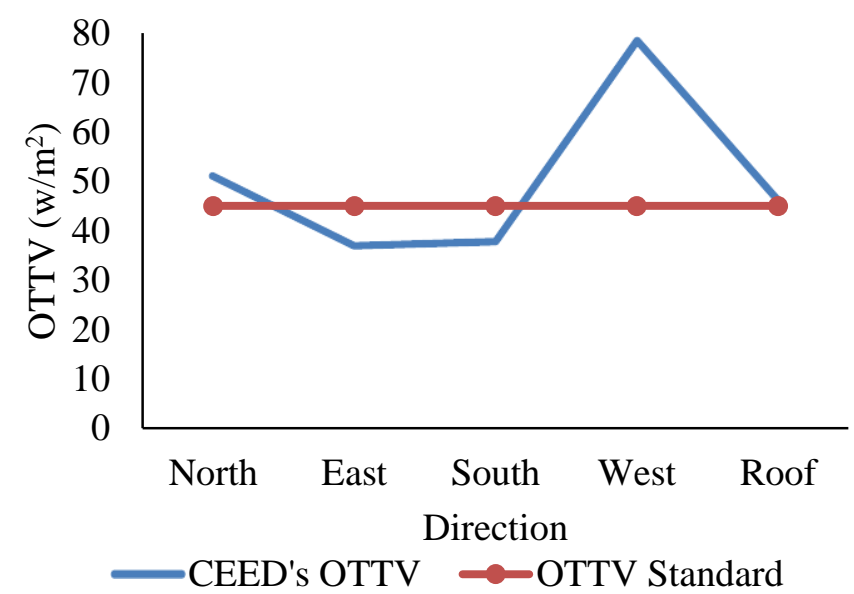

Figure 2. Comparison OTTV value with SNI on CEED building.

\subsubsection{IKE Calculation}

There are two variables that can be calculated on IKE building electricity, namely: IKE Gross which is total area of the air-conditioned room (with AC) plus total area of the non-air-conditioned room (non-AC), and IKE nett which is detailed IKE with clear separation per unit of total area between air-conditioned and nonair-conditioned rooms. 
Table 4. IKE based on electricity account bill of CEED building UGM 2015 and 2016.

\begin{tabular}{lllllll}
\hline Month & 2015 & & & 2016 \\
& $\begin{array}{l}\text { Electrical } \\
\text { Consumption } \\
(\mathrm{kWh})\end{array}$ & $\begin{array}{l}\text { Electrical } \\
\text { Cost }(\mathrm{Rp})\end{array}$ & $\begin{array}{l}\mathrm{IKE} \\
\left(\mathrm{kWh} / \mathrm{m}^{2} / \mathrm{month}\right)\end{array}$ & $\begin{array}{l}\text { Electrical } \\
\text { Consumption } \\
(\mathrm{kWh})\end{array}$ & $\begin{array}{l}\text { Electrical Cost } \\
(\mathrm{Rp})\end{array}$ & $\begin{array}{l}\text { Building IKE } \\
\left(\mathrm{kWh} / \mathrm{m}^{2} / \mathrm{month}\right)\end{array}$ \\
\hline January & 16,600 & $14,641,200.00$ & 3.01 & 19,000 & $18,098,640.00$ & 3.44 \\
February & 16,160 & $14,253,120.00$ & 2.93 & 19,320 & $18,403,459.20$ & 3.50 \\
March & 16,080 & $14,182,560.00$ & 2.91 & 19,200 & $18,289,152.00$ & 3.48 \\
April & 19,680 & $17,357,760.00$ & 3.57 & 20,120 & $19,165,507.20$ & 3.65 \\
May & 18,720 & $16,511,040.00$ & 3.39 & 23,280 & $22,175,596.80$ & 4.22 \\
June & 15,480 & $13,653,360.00$ & 2.80 & 18,680 & $17,793,820.80$ & 3.38 \\
July & 14,960 & $13,194,720.00$ & 2.71 & 86,80 & $8,268,220.80$ & 1.57 \\
August & 16,720 & $14,747,040.00$ & 3.03 & 21,240 & $20,232,374.40$ & 3.85 \\
September & 19,560 & $17,251,920.00$ & 3.54 & 19,840 & $18,889,790.40$ & 3.59 \\
October & 18,160 & $16,017,120.00$ & 3.29 & 18,400 & $17,527,104.00$ & 3.33 \\
November & 22,320 & $19,686,240.00$ & 4.04 & 23,240 & $20,479,680.00$ & 4.21 \\
December & 20,880 & $18,416,160.00$ & 3.78 & 17,680 & $15,593,760.00$ & 3.20 \\
\hline Average & 17,943 & $15,826,020.00$ & 3.25 & 19,057 & $16,807,980.00$ & 3.45 \\
\hline
\end{tabular}

Table 5. IKE based on electricity account bill of CEED building UGM 2015 and 2016.

\begin{tabular}{lllllll}
\hline Month & 2015 & \multicolumn{5}{l}{2016} \\
\cline { 2 - 7 } & $\begin{array}{l}\text { Electrical } \\
\text { Consumption } \\
(\mathrm{kWh})\end{array}$ & $\begin{array}{l}\text { Electrical } \\
\text { Cost }(\mathrm{Rp})\end{array}$ & $\begin{array}{l}\text { IKE } \\
\left(\mathrm{kWh} / \mathrm{m}^{2} / \mathrm{month}\right)\end{array}$ & $\begin{array}{l}\text { Electrical } \\
\text { Consumption } \\
(\mathrm{kWh})\end{array}$ & $\begin{array}{l}\text { Electrical Cost } \\
(\mathrm{Rp})\end{array}$ & $\begin{array}{l}\text { Building IKE } \\
\left(\mathrm{kWh} / \mathrm{m}^{2} / \mathrm{mon} \text { th }\right)\end{array}$ \\
\hline January & 3680 & $3,245,760.00$ & 0.75 & 3880 & $3,422,160.00$ & 0.67 \\
February & 3320 & $2,928,240.00$ & 0.72 & 2360 & $2,081,520.00$ & 0.57 \\
March & 3160 & $2,787,120.00$ & 0.77 & 4680 & $4,127,760.00$ & 0.98 \\
April & 4120 & $3,633,840.00$ & 0.93 & 3840 & $3,386,880.00$ & 0.76 \\
May & 2120 & $1,869,840.00$ & 0.57 & 3960 & $3,492,720.00$ & 0.98 \\
June & 4120 & $3,633,840.00$ & 0.95 & 1960 & $1,728,720.00$ & 0.40 \\
July & 2520 & $2,222,640.00$ & 0.57 & 3280 & $2,892,960.00$ & 1.64 \\
August & 2640 & $2,328,480.00$ & 0.59 & 3680 & $3,245,760.00$ & 0.01 \\
September & 2800 & $2,469,600.00$ & 0.79 & 3680 & $3,245,760.00$ & 0.99 \\
October & 3520 & $3,104,640.00$ & 1.02 & 3160 & $2,787,120.00$ & 0.86 \\
November & 3720 & $3,281,040.00$ & 0.99 & 3440 & $3,034,080.00$ & 0.93 \\
December & 3360 & $2,963,520.00$ & 0.82 & 3280 & $2,892,960.00$ & 0.68 \\
Average & 3257 & $2,872,380.00$ & 1.50 & 3433 & $3,028,200.00$ & 0.79 \\
\hline
\end{tabular}

KPFT and CEED buildings are using electrical energy source from PT. PLN (Persero) as the main supplier. Based on customer data, connection model and installation, the connection category in this building is categorized as medium voltage consumer with government fare $(\mathrm{P}-1 / \mathrm{TR})$ with power capacity of 164,350 VA $(164.35 \mathrm{kVA})$. Based on the data of monthly energy consumption in 2015 and 2016 as presented in Table 4 and Table 5 it is known that the monthly Energy Consumption Intensity in KPFT and CEED buildings based on IKE standard 5444rconditioned building that has been determined is still in the category of efficient.

\subsubsection{IKE Gross Calculation}

\section{a) KPFT Building}

On the basis of the secondary data of monthly electricity bills, calculation of IKE gross in 2015 and
2016 on KPFT building with an area of $5,519 \mathrm{~m}^{2}$ was done. To figure out the level of energy efficiency in each month in every year, a calculation was conducted based on this equation IKE $=($ total $\mathrm{kWh} / \mathrm{month} /$ gross area). For example, to calculate the IKE of November 2015 , this is how the calculation is done; IKE = $(22,320 \mathrm{kWh}) /\left(5,519 \mathrm{~m}^{2}\right)=4.04 \mathrm{kWh} / \mathrm{m}^{2} /$ month. Meanwhile, the calculation of IKE per year is calculated with this formula; IKE $=$ (total $\mathrm{Kwh} /$ year/gross area). For example, to calculate IKE of $2015 ; \mathrm{IKE}=(215,320 \mathrm{kWh}) /\left(5,519 \mathrm{~m}^{2}\right)=39.01$ $\mathrm{kWh} / \mathrm{m}^{2} /$ year.

Based on Table 6 regarding data of monthly energy consumption in 2015 and 2016 as shown, it was found out that the monthly Energy Consumption Intensity in KPFT building based on IKE standards for airconditioned buildings that have been determined is still in the category of efficient. 
Table 6. Category of energy consumption KPFT building on 2015-2016

\begin{tabular}{llllll}
\hline Month & 2015 & & 2016 & \multicolumn{2}{c}{ Information } \\
\cline { 2 - 5 } & IKE $\left(\mathrm{kWh} / \mathrm{m}^{2} / \mathrm{month}\right)$ & IKE $\left(\mathrm{kWh} / \mathrm{m}^{2} /\right.$ year $)$ & IKE $\left(\mathrm{kWh} / \mathrm{m}^{2} / \mathrm{month}\right)$ & IKE $\left(\mathrm{kWh} / \mathrm{m}^{2} /\right.$ year $)$ & Efficient \\
\hline January & 3.01 & 36.09 & 3.44 & 41.31 & Efficient \\
February & 2.93 & 35.14 & 3.50 & 42.01 & Efficient \\
March & 2.91 & 34.96 & 3.48 & 41.75 & Efficient \\
April & 3.57 & 42.79 & 3.65 & 43.75 & Efficient \\
May & 3.39 & 40.70 & 4.22 & 50.62 & Efficient \\
June & 2.80 & 33.66 & 3.38 & 40.62 & 18.87 \\
July & 2.71 & 32.53 & 1.57 & 46.18 & Efficient \\
August & 3.03 & 36.35 & 3.85 & 43.14 & Efficient \\
September & 3.54 & 42.53 & 3.59 & 40.01 & Efficient \\
October & 3.29 & 39.49 & 3.33 & 50.53 & Efficient \\
November & 4.04 & 48.53 & 4.21 & 38.44 & Efficient \\
December & 3.78 & 45.40 & 3.20 & & Efficient \\
\hline
\end{tabular}

Table 7. Category of energy consumption CEED Building on 2015-2016

\begin{tabular}{llllll}
\hline Month & 2015 & & 2016 & \multicolumn{2}{c}{ Information } \\
\cline { 2 - 5 } & IKE $\left(\mathrm{kWh} / \mathrm{m}^{2} / \mathrm{month}\right)$ & IKE $\left(\mathrm{kWh} / \mathrm{m}^{2} /\right.$ year $)$ & IKE $\left(\mathrm{kWh} / \mathrm{m}^{2} / \mathrm{month}\right)$ & IKE $\left(\mathrm{kWh} / \mathrm{m}^{2} /\right.$ year $)$ & Efficient \\
\hline January & 0.75 & 9.00 & 0.67 & 8.09 & E.78 \\
February & 0.72 & 8.61 & 0.57 & 11.74 & Efficient \\
March & 0.77 & 9.26 & 0.98 & 9,13 & Efficient \\
April & 0.93 & 11.22 & 0.76 & 11.74 & Efficient \\
May & 0.57 & 6.78 & 0.98 & 4.83 & Efficient \\
June & 0.95 & 11.35 & 0.40 & 19.70 & Efficient \\
July & 0.57 & 6.78 & 1.64 & 0.13 & Efficient \\
August & 0.59 & 7.04 & 0.01 & 11.87 & Efficient \\
September & 0.79 & 9.52 & 0.99 & 10.30 & Efficient \\
October & 1.02 & 12.26 & 0.86 & 11.22 & Efficient \\
November & 0.99 & 11.87 & 0.93 & 8.22 & Efficient \\
December & 0.82 & 9.78 & 0.68 & & Efficient \\
\hline
\end{tabular}

\section{b) CEED Building}

The area of CEED builing is $4,600 \mathrm{~m}^{2}$. As an example, calculation of IKE in april 2015 is $\mathrm{IKE}=(4,120$ $\mathrm{kWh}) /\left(4,600 \mathrm{~m}^{2}\right)=0.90 \mathrm{kWh} / \mathrm{m}^{2} / \mathrm{month}$. The calculation of IKE per year is calculated by formula; $\mathrm{IKE}=$ (total kwh/year/gross area). For example, to calculate IKE of 2015 is as follows, IKE $=(39,080$ $\mathrm{kWh}) /\left(4,600 \mathrm{~m}^{2)}=8.50 \mathrm{kWh} / \mathrm{m}^{2} /\right.$ year.

Based on Table 7, regarding data of monthly energy consumption in 2015 and 2016 as shown, it was found out that the monthly Energy Consumption Intensity in KPFT building based on IKE standards for airconditioned buildings that have been determined is still in the category of efficient.

\subsubsection{Calculation of IKE in AC and Non AC room}

\section{a) KPFT Building}

The proportion of areas of air-conditioned and nonair-conditioned rooms in KPFT building for each floor can be seen in Table 8 .
Table 8. Air-conditioned and unconditioned room area in KPFT building

\begin{tabular}{lllll}
\hline No & Floor & $\begin{array}{l}\text { Area } \\
\text { Total } \\
\left(\mathrm{m}^{2}\right)\end{array}$ & $\begin{array}{l}\text { Conditioned } \\
\text { Area }\left(\mathrm{m}^{2}\right)\end{array}$ & $\begin{array}{l}\text { Unconditioned } \\
\text { Area }\left(\mathrm{m}^{2}\right)\end{array}$ \\
\hline 1 & $1^{\text {st }}$ Floor & 2,093 & 0 & 2,093 \\
2 & $2^{\text {nd }}$ Floor & 1,461 & 808 & 653 \\
3 & $3^{\text {rd }}$ Floor & 1,965 & 1,322 & 643 \\
\hline \multicolumn{2}{l}{ Total } & 5,519 & 2,130 & 3,389 \\
\hline
\end{tabular}

This calculation is conducted to get the net IKE value in the KPFT building. To calculate the IKE in the rooms, it is necessary to firstly observe and collect the data of electronic device types, power capacity (watt), and the amount contained in the room.

Assumed that the operational activity (total working hours) is for 8 hours $(07: 30-15: 30)$, the load requirement for 5 days in a week ( 22 effective days in one month) equal to $70 \%$. Daily energy consumption for KPFT 3rd floor (Light $+\mathrm{AC}+$ other loads) $=$ $32.09 \mathrm{~kW}$ x 8 hours x $0.70=179.71 \mathrm{kWh} /$ day $($ SEE Table 9). 
Consumption of electric energy per month $=179.71$ $\mathrm{kWh} /$ day $\mathrm{x} 22$ days $=3,953.49 \mathrm{kWh} /$ month.

The are of air-conditioned room on the 3rd floor is $1,322 \mathrm{~m}^{2}$. IKE of AC room in 3rd floor $=3,953.49$ $\mathrm{kWh} / \mathrm{month} / 1,322 \mathrm{~m}^{2}=2.99 \mathrm{kWh} / \mathrm{m}^{2} /$ month.

The first floor (typical) of the KPFT building is an open hall without walls, so the calculation of the electrical load is only done on a load of light and other loads without HVAC load with the following details.

Lighting load $=2628$ watts $/$ day or $2,628 \mathrm{~kW} /$ day

HVAC load $=0$

Other loads $=1000$ watts $/$ day or $1.00 \mathrm{~kW} /$ day

Total electrical load $=($ Lighting + HVAC + other loads $)$

$=(2,628+0+1,000)=3,628$ Watts $/$ day $=3.628 \mathrm{~kW} /$ day.

Calculation of energy consumption on the 1st floor is assumed starting when the lights are turned on until the end of the activities in the hall which is at 17.00$22.00 \mathrm{pm}$ every day. So, daily load on the 1 st floor can be calculated: $3,628 \times 5=18,140$ watts/day or $18.14 \mathrm{~kW} /$ day and per month $18,140 \times 30=544,200$ Watt $/$ month or $544.20 \mathrm{~kW} /$ month. The are on the first floor is $2,093 \mathrm{~m}^{2}$. Therefore, the consumption of nonair-conditioned room on the 1 st floor is 544.20 $\mathrm{kW} / \mathrm{month} / 2,093 \mathrm{~m}^{2}=0.26 \mathrm{kWh} / \mathrm{m}^{2} /$ month.

\section{b) CEED Building}

The proportion of air-conditioned and non-airconditioned rooms in Civil Engineering and Environmental Department buildings for each floor can be seen in Table 10 and Calculations of IKE of air-conditioned and non-AC rooms are presented in Table 11 and Table 12.

Based on the calculation of Energy Consumption Intensity (IKE) in the main CEED building presented in Table 11, average IKE per unit of area of the airconditioned room is $4.40 \mathrm{kWh} / \mathrm{m}^{2} /$ month and from Table 12 it is figured out that the average IKE per unit of area of non-air-conditioned room is 1.40 $\mathrm{kWh} / \mathrm{m}^{2} /$ month. Based on the established standard, it is found out that air-conditioned room is categorized as very efficient, while non-air-conditioned room is categorized as efficient

Table 10. Air-conditioned and unconditioned room area in CEED building

\begin{tabular}{lllll}
\hline No & Floor & $\begin{array}{l}\text { Area } \\
\text { Total } \\
\left(\mathrm{m}^{2}\right)\end{array}$ & $\begin{array}{l}\text { Conditioned } \\
\text { Area }\left(\mathrm{m}^{2}\right)\end{array}$ & $\begin{array}{l}\text { Unconditioned } \\
\text { Area }\left(\mathrm{m}^{2}\right)\end{array}$ \\
\hline 1 & 1st Floor & $1,302.48$ & 847.80 & 454.68 \\
2 & $\begin{array}{l}\text { 2nd } \\
\text { Floor }\end{array}$ & $1,211.76$ & 963.36 & 248.40 \\
3 & 3rd Floor & $1,097.64$ & 879.12 & 218.52 \\
\hline \multicolumn{2}{l}{ Total } & $3,611.88$ & $2,690.28$ & 921.60 \\
\hline
\end{tabular}

Table 9. IKE in Air Conditioned Rooms KPFT building.

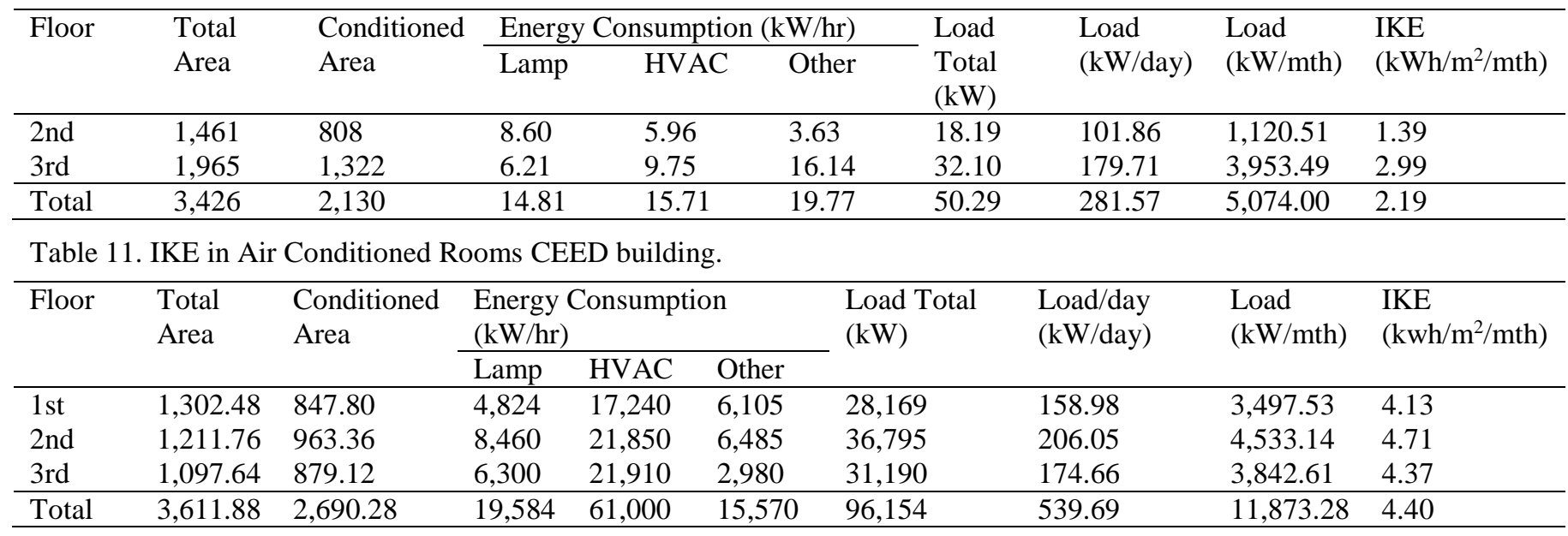

Table 12. IKE in Air Conditioned Rooms KPFT building.

\begin{tabular}{|c|c|c|c|c|c|c|c|c|c|}
\hline \multirow[t]{2}{*}{ Floor } & \multirow{2}{*}{$\begin{array}{l}\text { Total } \\
\text { Area }\end{array}$} & \multirow{2}{*}{$\begin{array}{l}\text { Unconditioned } \\
\text { Area }\end{array}$} & \multicolumn{3}{|c|}{ Energy Consumption $(\mathrm{kW} / \mathrm{hr})$} & \multirow{2}{*}{$\begin{array}{l}\text { Load } \\
\text { Total } \\
(\mathrm{kW})\end{array}$} & \multirow{2}{*}{$\begin{array}{l}\text { Load/ } \\
\text { day } \\
(\mathrm{kW} / \mathrm{day})\end{array}$} & \multirow{2}{*}{$\begin{array}{l}\text { Load/mth } \\
\text { (kWh/mth) }\end{array}$} & \multirow{2}{*}{$\begin{array}{l}\text { IKE } \\
\left(\mathrm{kWh} / \mathrm{m}^{2} / \mathrm{mth}\right)\end{array}$} \\
\hline & & & Lamp & Lamp & Lamp & & & & \\
\hline 2nd & $1,302.48$ & 454.68 & 0.609 & 2.391 & 3.00 & 16.80 & 369.60 & 0.813 & 1302.48 \\
\hline 3rd & $1,211.76$ & 248.40 & 0.587 & 0.400 & 0.99 & 5.54 & 121.97 & 0.491 & 1211.76 \\
\hline Total & $1,097.64$ & 218.52 & 4.929 & 0.200 & 5.13 & 28.72 & 631.89 & 2.892 & 1097.64 \\
\hline
\end{tabular}




\subsubsection{Recommendation on Opportunities for Energy Efficiency Increase}

The need for air conditioning to create comfort in the rooms of both buildings has resulted in energy consumption, in this case, the electrical load, for air conditioner becomes greater than the electrical energy consumption of other electrical equipment. High electrical loads on air conditioner equipment results to an increase of operational expenses in both buildings. Percentage of electricity expense between KPFT and CEED Building are shown in Figure 3 and Figure 4.

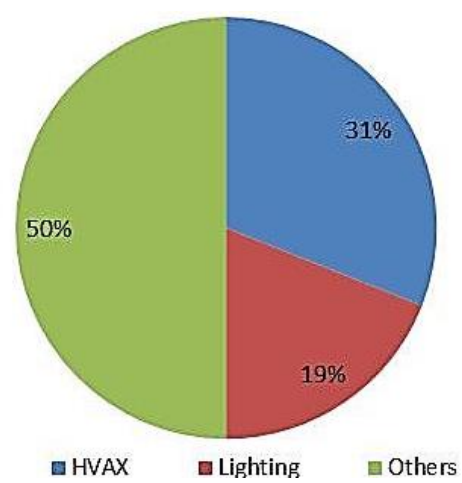

Figure 3. Percentage of electricity expense KPFT building.

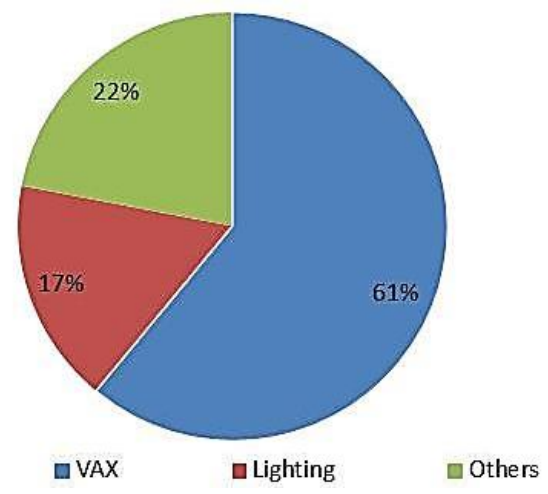

Figure 4. Percentage of electricity expense CEED building.

Based on the profile of energy usage in KPFT building and CEED building, in order to avoid waste and to improve the efficiency of energy consumption in the air conditioning activities without having to reduce the comfort level for the building occupants, it takes some efforts of repair, replacement and addition of components in the building, and also the application of better procedures for the building occupants.

a) Analysis of the Implementation of Opportunities for Energy Efficiency against KPFT Building

As an effort to increase the efficiency of electrical energy consumption in air conditioning load in the KPFT building is to evaluate the calculation of heat or solar radiation based on the type of window glass used in the building in order to reduce heat absorption into the room. As a matter of fact, the hall located on the 2nd floor or known as R. 2.3 of the KPFT building has a window as big as $10.8 \mathrm{~m}^{2}$. Using clear glass for the window, the average solar radiation is $(I)=700$ $\mathrm{W} / \mathrm{m}^{2}$. Since the angle of the sun towards the window is $30^{\circ}$, clear glass has shading coefficient $\theta=0.7$. Thus, heat penetrating the glass can be figured out.

The heat penetrating through the glass

Qs $\quad=A I \theta . W=10.8 \times 700 \times 0.7=5,292 \mathrm{~W}$

This type of clear glass provides a fairly high transmission that is about $90 \%$.

As an effort to decrease the amount of heat that penetrates through the glass, the glass can be replaced with rayben glass type which has a shading coefficient $\theta=0.7$. The result of the calculation is as follows.

The heat penetrating through the glass

Qs $\quad=A I \theta . W=10.8 \times 700 \times 0.57=4,309.2 \mathrm{~W}$

Replacement to Rayben glass type (tinted glass) is proven to reduce the amount of heat since it has a fairly high heat absorption which is about $55 \%$, so it will reduce the load on air-conditioning (HVAC) and give comfort to building occupants. Using the same calculation method, further calculations are done to some other room as presented in Table 13.

Table 13. Result of calculation of cooling load KPFT building.

\begin{tabular}{llllllll}
\hline Room & & Window $\left(\mathrm{m}^{2}\right)$ & Solar radiation $\left(\mathrm{W} / \mathrm{m}^{2}\right)$ & \multicolumn{2}{c}{ Shading coefficient } & \multicolumn{2}{c}{ Solar heat through the glass $(\mathrm{W})$} \\
\cline { 5 - 8 } & & & Clear glass & Raybean glass & Clear glass & Raybean glass \\
\hline 2nd Floor & R.2.1 & 32.24 & 700 & 700 & 0.7 & 0.57 & $15,797.60$ \\
& R.2.2 & 14.40 & 700 & 0.7 & 0.57 & $7,056.00$ & $5,745.60$ \\
& R.2.3. & 10.80 & 700 & 0.7 & 0.57 & $5,592.00$ & $4,309.20$ \\
& R.2.4 & 10.80 & 700 & 0.7 & 0.57 & $5,592.00$ & $4,309.20$ \\
3rd Floor & R.2.5 & 14.40 & 700 & 0.7 & 0.57 & $7,056.00$ & $5,745.60$ \\
& R.3.1 & 29.12 & 700 & 0.7 & 0.57 & $14,268.80$ & $11,618.88$ \\
& R.3.2 & 19.92 & 700 & 0.7 & 0.57 & $9,760.80$ & $7,948.08$ \\
& R.3.3. & 27.04 & 700 & 0.7 & 0.57 & $13,249.60$ & $10,788.96$ \\
& R.3.4 & 27.04 & 700 & 0.7 & 0.57 & $9,249.60$ & $10,788.96$ \\
& R.3.5 & 19.92 & & & & $9,760.80$ & $7,948.08$ \\
\hline
\end{tabular}


b) Analysis of the Implementation of Opportunities for Energy Efficiency against CEED Building

In order to increase the efficiency of electric energy consumption in the air conditioning load, calculation of cooling needs by thermal balance method was carried out in some rooms in the CEED building.

In the calculation of cooling needs with thermal balance method in undergraduate administration room in the $2^{\text {nd }}$ floor of CEED building, the dimensions of the room; length: $14.4 \mathrm{~m}$, width: $14.4 \mathrm{~m}$, and height: $3.5 \mathrm{~m}$. It used the split type air conditioner. The east and west walls are directly exposed to outer space, consisting of a solid concrete wall as thick as $152 \mathrm{~mm}$, the transmittance $\left(\mathrm{U}\right.$ wall) $=3.58 \mathrm{~W} / \mathrm{m}^{2 \circ} \mathrm{C}$, wall absorption $(\alpha)=0.58$, sizes of window for each side of the east and west with a width of 12.96 and a height of 2.05 with raybean glass type which transmittance values $\left(\mathrm{U}_{\text {glass }}\right)$ is $4.48 \mathrm{~W} / \mathrm{m}^{2 \circ} \mathrm{C}$, at the time of the calculation, the angle of incidence of the sun on the wall and Glass $(\beta)$ was $60^{\circ}$. Average solar radiation (I) $=700 \mathrm{~W} / \mathrm{m}^{2}$, the transmittance of $\operatorname{air}\left(\mathrm{f}_{\mathrm{o}}\right)=10$ $\mathrm{W} / \mathrm{m}^{2 \circ} \mathrm{C}$, hot air type $1,300 \mathrm{~J} / \mathrm{m}^{3 \circ} \mathrm{C}$, ventilation $=0.5$ $\mathrm{ACH}$, indoor temperature $\left(\mathrm{T}_{\mathrm{i}}\right) 24^{\circ} \mathrm{C}$ (comfortable condition), outdoor temperature $\left(\mathrm{T}_{\mathrm{o}}\right)$ was measured at $31^{\circ} \mathrm{C}$. The room contains 16 administrative personnel using 12 fluorescent lamps (TL lamps) @ 36 watts, each person was assumed to generate $140 \mathrm{~W}$ heat. Based on those data, the cooling load required is:

External wall surface temperature:

$\mathrm{T}_{\mathrm{s}}=\mathrm{T}_{\mathrm{o}}+\left(\mathrm{I} \cdot \alpha \cos \beta / \mathrm{f}_{\mathrm{o}}\right)=51.3{ }^{\circ} \mathrm{C}$

Then

$\Delta \mathrm{T}_{\text {wall }}=\mathrm{T}_{\mathrm{S}}-\mathrm{T}_{\mathrm{i}}=51.3-24=27.3^{\circ} \mathrm{C}$

$\Delta \mathrm{T}_{\text {glass }}=\mathrm{T}_{\mathrm{o}}-\mathrm{T}_{\mathrm{i}}=31-24=7^{\circ} \mathrm{C}$

The formula for cooling needs is:

$\mathrm{Qm}=\mathrm{Qi}+\mathrm{Qs}+\mathrm{Qc}+\mathrm{Qv}$

Qi $=\Sigma$ heat (human, electrical equipment)

$=(12)(36)+(16)(140) \quad=2,672 \mathrm{~W}$

Qs = solar heat through the glass

$=\mathrm{A}_{\text {glass. }}$ I. $\theta=(12.96)(2.05)(2)(700)(0.75)$

$=27,896.4 \mathrm{~W}$
$\mathrm{Qc}=$ heat through wall + heat through glass

$=\mathrm{A}_{\text {wall }} \cdot \mathrm{U}_{\text {wall }} \cdot \Delta \mathrm{T}+\mathrm{A}_{\text {glass. }} \mathrm{U}_{\text {glass }} . \Delta \mathrm{T}$

$=((14.4)(1.45)(2)(3.58)(27.3))+((12.96)(2.05)$

$(2)(4.48)(7))=5,747.72 \mathrm{~W}$

$\mathrm{Qv}=$ heat for ventilation $=1,300 . \mathrm{V} \cdot \Delta \mathrm{T}$

$=1,300 .((14.4)(14.4)(3.5)(0.5) / 3,600))(7)=917.28 \mathrm{~W}$

$\mathrm{Qm}=\mathrm{Qi}+\mathrm{Qs}+\mathrm{Qc}+\mathrm{Qv}$

$=2,972+27,896.4+5,747.72+917.28=37.53 \mathrm{~kW}$

Based on the performed calculation, it was found out that the heat that went through the undergraduate administrative room on the 2nd floor of the CEED building was very high. Therefore, any afforts to minimilize the load are needed. Some possible efforts to do:

a) Preventing solar radiation by installing wide enough shades or by using a glass type which has a high solar absorption.

b) Reducing the heat load can also be achieved by using energy-efficient bulbs. It is recommended to use 12 energy-save CFL bulbs (Compact Fluorescent Lamp) @ 24 W with the assumption that each bulb produces $24 \mathrm{~W}$ of heat as well.

c) It is recommended that the inside part of the normal concrete wall is coated with a $25 \mathrm{~mm}$ cork board which can make the transmittance value of the wall become $0.85 \mathrm{~W} / \mathrm{m}^{2 \circ} \mathrm{C}$.

Furthermore, a re-calculation was done to find out how much is the efficiency of cooling load in the undergraduate administrative room on the 2 nd floor of CEED building which in the existing condition is known to have a cooling load as much as $37,533.4 \mathrm{~W}$ or $37.53 \mathrm{~kW}$ and after implementing some repair and addition of wall components, it decreased down significantly to $6,080.66 \mathrm{~W}$ or $6.08 \mathrm{~kW}$ so that the efficiency improvements in AC loads can also be lowered. With the same calculation assumption, further calculation was carried out in some other rooms as shown in Table 14. 
Table 14. Result of calculation of cooling load CEED building.

\begin{tabular}{|c|c|c|c|c|c|c|c|c|c|c|c|}
\hline \multirow[t]{2}{*}{ Level } & & \multirow{2}{*}{$\begin{array}{l}\text { Room } \\
\text { Function }\end{array}$} & \multicolumn{3}{|l|}{ Wall } & \multirow{2}{*}{$\begin{array}{l}\text { Window } \\
\left(\mathrm{m}^{2}\right)\end{array}$} & \multicolumn{4}{|c|}{ Energy for cooling } & \multirow{2}{*}{$\begin{array}{l}\mathrm{Q}_{\mathrm{m}} \\
(\mathrm{W})\end{array}$} \\
\hline & & & $\mathrm{p}$ & 1 & $\mathrm{t}$ & & $\mathrm{Q}_{\mathrm{i}}(\mathrm{W})$ & $\mathrm{Q}_{\mathrm{s}}(\mathrm{W})$ & $\left.Q_{c} W\right)$ & $\mathrm{Q}_{\mathrm{v}}(\mathrm{W})$ & \\
\hline \multirow{3}{*}{$\begin{array}{l}1^{\text {st }} \\
\text { Floor }\end{array}$} & R. 202 & Adm. & 14.4 & 14.4 & 3.5 & 26.57 & 2,528 & 0 & 2,635 & 917.28 & $6,080.66$ \\
\hline & & room & & & & & & & & & \\
\hline & R. 206 & $\begin{array}{l}\text { Meeting } \\
\text { room }\end{array}$ & 7.2 & 3.6 & 3.5 & 15.33 & 1,826 & 0 & 1,501 & 114.66 & $3,441.75$ \\
\hline \multirow[t]{4}{*}{$\begin{array}{l}3^{\text {rd }} \\
\text { Floor }\end{array}$} & R. 301 & $\begin{array}{l}\text { Meeting } \\
\text { room }\end{array}$ & 18.0 & 12.6 & 3.5 & 70.45 & 28,109 & 0 & 7,311 & $1,003.28$ & $36,423.86$ \\
\hline & R. 303 & $\begin{array}{l}\text { Meeting } \\
\text { room }\end{array}$ & 14.4 & 7.2 & 3.5 & 25.58 & 7,404 & 0 & 2,843 & 458.64 & $10,705.64$ \\
\hline & R. 307 & Classroom & 14.4 & 14.4 & 3.5 & 51.16 & 15,692 & 0 & 3,645 & 917.28 & $20,254.34$ \\
\hline & R. 310 & Classroom & 14.4 & 14.4 & 3.5 & 51.16 & 15,800 & 0 & 3,645 & 917.28 & $20,362.34$ \\
\hline
\end{tabular}

\section{CONCLUSIONS}

a) The average temperature of the KPFT building is $28.4^{\circ} \mathrm{C}$, while its average relative humidity is $62 \%$. Meanwhile, the average temperature of the CEED building is $28.4^{\circ} \mathrm{C}$, while its average relative humidity is $65 \%$. Based on those results, it can be concluded that in order to achieve thermal comfort which temperature is around $24^{\circ} \mathrm{C}$ and relative humidity is around $60 \%$, a quite intensive air conditioning is still needed in both buildings.

b) OTTV value of the KPFT building is $17.61 \mathrm{~W} / \mathrm{m}^{2}$, while CEED building OTTV value is $43.05 \mathrm{~W} / \mathrm{m}^{2}$. Those values are still below the standard of SNI which is $45 \mathrm{~W} / \mathrm{m}^{2}$. The OTTV value of CEED building is higher than KPFT building because the direction of its glass windows are facing on the west and east which get direct exposure of sunlight which makes heat radiation penetrating through the rooms in the CEED building is also higher.

c) The IKE gross value indicates that the KPFT building has average IKE value per month as much as $3.25 \mathrm{kWh} / \mathrm{m}^{2}$ in 2015 and as much as $3.45 \mathrm{kWh} / \mathrm{m}^{2}$ in 2016. Meanwhile, the CEED building has average IKE value per month as much as $1.50 \mathrm{kWh} / \mathrm{m}^{2}$ in the year of 2105 and as much as $0.79 \mathrm{kWh} / \mathrm{m}^{2}$ in 2016 which are still in the category of EFFICIENT. The significant lowering of IKE value of CEED building is affected by the fact that there was some replacement of electrical appliances in the building in 2016, specifically replacement of the air conditioner to a more energy-efficient airconditioner, while no such replacement was done in the KPFT building.

d) A couple of efforts to improve the efficiency of electrical energy consumption in air conditioning activity (HVAC) in KPFT building that can be taken are 1) replacing the air conditioner (AC) 2) replacing the glass window with a better heat absorbance glass.

e) Several efforts to improve the efficiency of electrical energy consumption in the airconditioning activities (HVAC) in CEED building that can be done: 1) adding a sunshade to avoid direct solar radiation on the glass. 2) adding some layer in the inner part of the wall which has lower transmittance value.

\section{SUGGESTIONS}

a) To increase the quantity or number as well as various functions of the buildings to be taken as the study case objects

b) To add more measurement variables in order to strengthen the arguments, similarities, differences as well as to provide alternative solutions to be offered.

c) To involve the residents or users of the building in direct research.

\section{REFERENCES}

ASEAN-USAID, 1992. Building Energy Conservation Project, Final Report, June 1992, United States: ASEAN Lawrence Berkeley Laboratory.

Badan Standarisasi Nasional, 2011. SNI 6197:2011 tentang Prosedur Audit Energi pada Bangunan Gedung. Jakarta: Badan Standarisasi Nasional.

Badan Standarisasi Nasional, 2011. SNI 6389:2011 tentang Konservasi Energi Selubung Bangunan pada Bangunan Gedung. Jakarta: Badan Standarisasi Nasional.

Krishan, A., 2001. Climate Responsive Architecture: A Design Handbook for Energy Efficient Buildings. New York: McGraw-Hill Book Company. 
Marzuki, A. \& Rusman, 2012. Audit Energi pada Bangunan Gedung Direksi PT. Perkebunan Nusantara XIII (Persero0, Pontianak: Department of Electrical Engineering, Politeknik Negeri Pontianak.

Ministry of Energy and Mineral Resources, 2012. Ministry Law No.13 Year 2012 Tentang Penghematan Pemakaian Energi Listrik. Jakarta: Directorate General of Energy Saving.

Satwiko, P., 2009. Fisika Bangunan [Physics of Building]. Yogyakarta: Penerbit Andi.
Syarifudin, 2017. Analisis Konsumsi Energi pada Operasional Bangunan Gedung Kampus [Analysis of Energy Consumption towards Campus Building Operational], Yogyakarta: Master Thesis, Faculty of Engineering, Universitas Gadjah Mada.

Yuliatna, F., 2015. Analisis Perbandingan Konsumsi Energi pada Kegiatan Operasional dan Pemeliharaan Bangunan Gedung dengan Konsep Green Building dan Bangunan Gedung Konvensional, Yogyakarta: Faculty of Engineering, Universitas Gadjah Mada. 
[this page is intentionally left blank] 